\title{
Experimental method for the selection of points of measurement diagnostic vibration signals on internal combustion engine
}

\begin{abstract}
The diagnostic testing of internal combustion engine can be made by using working processes and methods which take advantage of leftover processes. Working processes give information about general condition of internal combustion engine. Leftover processes give information about condition of particular subassemblies and kinematic couples; hence they are used as autonomous processes or as processes supporting other diagnostic methods. Methods based on analysis of vibrations and noise changes to determine technical condition of object are named as vibroacoustic diagnostics. In papers about vibroacoustic diagnostics of engine, problems connected with difficulty to select test point and to define diagnostic parameters containing essential information about engine's condition, are most often omitted. Selection of engine's working parameters and conditions of taking measurements or recording vibration signal are usually based on references, researcher's experience or intuition. General assumptions about taking measurements of signal closest to its source are most often used. This paper presents a new approach to vibroacoustic diagnostics of internal combustion engine. Selection of test points of vibration on the basis of impact tests results was suggested and performed a sensitivity analysis of measurement points on the cylinder head, the force impulse.
\end{abstract}

Key words: diagnostic, internal combustion engine, impact test

\section{Eksperymentalna metoda wyboru punktów pomiaru diagnostycznych sygnałów drganiowych na silniku spalinowym}

\begin{abstract}
Diagnostyka silników spalinowych opiera się na metodach wykorzystujacych procesy robocze (indykowanie, zmiany momentu obrotowego w funkcji obrotu wału korbowego, pomiar ciśnienia i temperatury spalin, ciśnienia w przestrzeni nad i pod tłokiem, parametrów zasilania, zadymienia spalin itp.) oraz procesy resztkowe (drgania, hałas, procesy termiczne, elektryczne i inne). Na podstawie wyników badań procesów roboczych można wnioskować o ogólnym stanie silnika spalinowego, natomiast procesy resztkowe daja informacje o stanie poszczególnych podzespołów i par kinematycznych. Dlatego procesy resztkowe wykorzystuje sie jako autonomiczne lub wspomagajace inne metody diagnostyczne. Wszystkie metody oparte na analizie zmian drgań i hałasu dla określenia stanu technicznego obiektu nosza nazwę diagnostyki wibroakustycznej. W pracach poświęconych diagnostyce wibroakustycznej silnika najczęściej pomija się zagadnienia zwiąane z problemem wyboru punktu pomiarowego oraz określenia parametrów diagnostycznych zawierajacych istotne informacje o stanie silnika. Dobór parametrów pracy silnika oraz warunków dokonania pomiaru lub zapisu sygnału drganiowego opiera się zazwyczaj na wiedzy literaturowej, doświadczeniu lub intuicji badacza. Bardzo często korzysta się z ogólnych przesłanek dotyczacych pomiaru sygnałów jak najbliżej źródła ich powstawania. W artykule przedstawiono metodę wyboru punktów rejestracji sygnałów drgań, opierająca się na analizie wyników testów impulsowych głowicy silnika spalinowego.
\end{abstract}

Słowa kluczowe: diagnostyka, silnik spalinowy, test impulsowy

\section{Introduction}

In the capacity of drive units in the rail vehicles among other things the self-ignition internal combustion engines (I. C. engines) of medium and high power rating are used. Diagnosing of their technical condition enables to carry out an overhaul policy conditioned by technical condition, to prevent most of unplanned outages and by detecting defects in early stage, to decrease significantly the scope and the cost of overhaul and service. Safety of transportation and their timelines constitute a separate issue.

To assess technical condition and working conditions (functional and operation parameters) of combustion engine, parameters and characteristics of vibration signal generated by combustion engine [ $1-3]$ are more and more often used. However, receiving from vibrations diagnostically useful information is not easy. It is difficult to identify and to de-

\section{Wprowadzenie}

Jako elementy jednostek napędowych pojazdów szynowych stosowane są między innymi silniki spalinowe o zapłonie samoczynnym (ZS) średniej i dużej mocy. Diagnozowanie ich stanu technicznego pozwala prowadzić politykę remontową uwarunkowaną stanem technicznym, zapobiegać większości nieplanowanych postojów, a dzięki wykryciu uszkodzeń we wczesnym stadium rozwoju radykalnie zmniejszyć zakres i koszty napraw i obsługi. Odrębnym aspektem są względy bezpieczeństwa przewozów oraz ich terminowość.

Do oceny stanu technicznego lub oceny stanu pracy (parametrów funkcjonalnych i operacyjnych) silnika spalinowego coraz częściej wykorzystywane są miary i charakterystyki sygnału drganiowego generowanego przez silnik spalinowy [1 - 3]. Pozyskanie informacji użytecznej diagnostycznie, 
duct the technical or working condition of engine's part or subassembly on the basis of commonly used parameters and characteristics of vibroacoustic signal (VA), stems, among others, from complex nature of vibrations generated by engine, processes proceeding inside, coexistence of many sources of vibrations and complex kinetics.

This study hereafter will show the problem of choosing on the engine head the point of acquisition of the vibration signals for diagnostic testing (for the valve clearance assessing).

\section{Choosing the acquisition point of the vibration signals}

To assess technical condition of combustion engine, parameters of accompanying processes, working processes and parameters of processes used in nondestructive tests (e.g. ultrasounds) are used as a vector signal. The following values describe working processes used in diagnostic testing of combustion engines: power, torque, reaction torque, instantaneous angular speed and turning angle of crankshaft etc. They are used as conceptualized parameters of technical condition of an engine.

Parameters of accompanying processes (vibrations, noise, thermal processes, wear etc.) are used to diagnose detailed technical condition of engine and to localize failures. In diagnostic testing of combustion engine, vibroacoustic processes (vibrations, noise) are the most often used accompanying processes.

Because of placing the vibration transducers has strong influence on the results received after diagnostic signals analysis, in the course of drawing up a method for the diagnostic testing the important thing is choosing the point of vibration signal acquisition. In extreme case the place of vibration measurement improperly chosen might give wrong conclusions about the technical condition of combustion engine.

\section{Research methodology}

Combustion engine a $8 \mathrm{C} 22$ were the research object. This engine is used, among others, to drive diesel locomotive type SM 42, power generators and as supporting engines in watercrafts. It is a medium-speed, four cycle, V-engine with direct injection supercharged with turbo compressors with cooling of supercharging air. Research referring to defining frequencies of proper vibrations of engine's parts and units were carried out according to active experiment. Active experiment consists in purposeful change of input or disturbing parameters and observing influence of those changes on input parameters. Excitation power in impact tests was taken as input parameter and vibration accelerations of combustion engine's cylinder head are taken as output parameters.

The vibration transducers type 4504 [7] made by Brüel \& Kjær company were chosen following the instructions comprised in the study $[4,5]$ and their frequency band was up to $18 \mathrm{kHz}$. In the course of diagnostic testing the signals in the band range from $0.1 \mathrm{~Hz}$ to $25 \mathrm{kHz}$ were recorded. The sampling frequency was adjusted to the value of $65536 \mathrm{~Hz}$ and the accelerometers were mounted on the engine head zawartej w drganiach nie jest łatwe. Trudność identyfikacji i wnioskowania o stanie technicznym lub pracy elementu albo podzespołu silnika na podstawie powszechnie stosowanych miar i charakterystyk sygnału wibroakustycznego (WA) wynika między innymi ze złożonej natury drgań generowanych przez silnik, zachodzących w nim procesów, koegzystencji wielu źródeł drgań, a także złożonej kinematyki.

$\mathrm{W}$ artykule będzie przedstawiony problem wyboru punktu akwizycji sygnałów drgań na głowicy silnika spalinowego do celów diagnostycznych (oceny luzów zaworów).

\section{Wybór punktu akwizycji sygnałów drgań}

Jako wektor sygnału do oceny stanu technicznego silnika spalinowego wykorzystywane są parametry procesów towarzyszących, roboczych oraz parametry procesów wykorzystywanych w badaniach nieniszczących (np. ultradźwięki). Wielkościami opisującymi procesy robocze stosowanymi w diagnostyce silników spalinowych są: moc, moment obrotowy i reakcyjny, chwilowa prędkość kątowa i kąt skręcenia wału korbowego itp.; są one stosowane jako uogólnione parametry stanu technicznego silnika.

Parametry procesów towarzyszących (drgania, hałas, procesy termiczne, zużycia itp.) są stosowane do diagnozowania szczegółowego stanu technicznego silnika oraz lokalizacji niezdatności. Do najczęściej wykorzystywanych procesów towarzyszących w diagnostyce silników spalinowych należą procesy wibroakustyczne (drgania i hałas).

Ważnym zagadnieniem $\mathrm{w}$ trakcie opracowywania metodyki badań diagnostycznych jest wyznaczenie punktu akwizycji sygnałów drgań, ponieważ umiejscowienie przetworników drgań ma znaczący wpływ na otrzymane wyniki analiz sygnałów diagnostycznych. W ekstremalnym przypadku nieprawidłowo wybrane miejsce pomiaru drgań może prowadzić do błędnych wniosków dotyczących stanu technicznego silnika spalinowego.

\section{Metodyka badań}

Obiektem badań był silnik spalinowy a8C22. Silnik ten jest stosowany między innymi do napędu lokomotyw spalinowych serii SM 42, agregatów prądotwórczych oraz jako silnik pomocniczy jednostek pływających. Jest to widlasty, średnioobrotowy silnik czterosuwowy z wtryskiem bezpośrednim, doładowany dwoma turbosprężarkami z chłodzeniem powietrza doładowującego.

Badania dotyczące wyznaczenia częstotliwości drgań własnych głowicy silnika spalinowego przeprowadzono, opierając się na założeniach eksperymentu czynnego, który polega na celowej zmianie parametrów wejściowych lub zakłócających i obserwacji wpływu tych zmian na parametry wyjściowe. Za parametr wejściowy przyjęto siłę wymuszającą w testach impulsowych, natomiast za parametry wyjściowe - przyspieszenia drgań wybranych elementów i zespołów silnika spalinowego.

Przetworniki drgań typu 4504 [7] firmy Brüel\&Kjær wybrano na podstawie wskazówek zawartych w pracach [4, 5], liniowe pasmo przenoszenia wybranych przetworników wynosiło do $18 \mathrm{kHz}$. Podczas badań rejestrowano sygnały w paśmie $0,1 \mathrm{~Hz}-25 \mathrm{kHz}$. Częstotliwość próbkowania 
by glue. To choose the places of measurement a principle that the transducer should be put in the place accessible and closest to the area where the working valves generate the vibration signals was taken $[1,6]$.To recording the vibration signals three pieces of the tri-axial vibration converters (P1, P2, P3) were used. There were taken the following directions of the measurement of vibrations: 1) direction $X$ - parallel with the cylinder radius, 2) direction $\mathrm{Z}$ - parallel with the cylinder axle, 3 ) direction $Y$ - perpendicular to two previous directions.

Figure 1 presents a view of the head of cylinders in the tested engine while Fig. 2 - the spatial orientation of the transducers for vibration measurements and the places of their mounting on tested object. To recording the vibration signals a Multi-Analyzer PULSE made by the Brüel \& Kjær company was used. The view of the measurement equipment in diagnostic post is shown in Fig. 3.

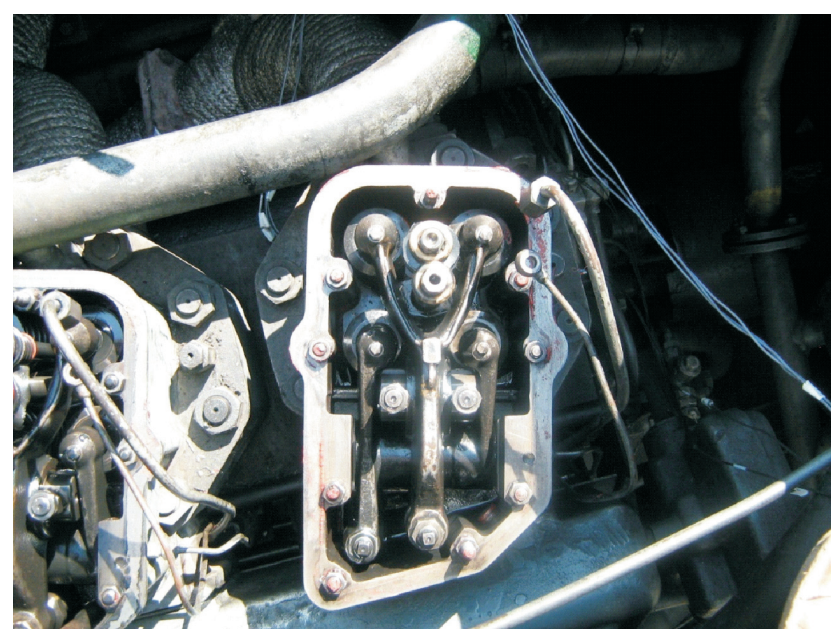

Fig. 1. View of the cylinder head engine's on the locomotive SM42 (engine a8C22)

Rys. 1. Głowica cylindrów silnika lokomotywy SM42 (silnik a8C22) ustawiono na $65536 \mathrm{~Hz}$. Akcelerometry zamocowano na głowicy silnika spalinowego za pomocą kleju. Przy wyborze miejsc pomiarowych przyjęto zasadę, że przetwornik powinien znajdować się jak najbliżej miejsca generacji sygnału drgań związanego z pracą zaworów oraz w miejscu dostępnym $[1,6]$. Do rejestracji drgań użyto trzech trójosiowych przetworników drgań (P1, P2, P3). Orientacje kierunków pomiaru drgań przyjęto następująco: kierunek $\mathrm{X}$ równoległy do promienia cylindra, kierunek $\mathrm{Z}$ równoległy do osi cylindra, kierunek Y prostopadły do dwóch pozostałych.

Głowicę cylindrów badanego silnika przedstawiono na rys. 1, a orientację przestrzenną przetworników do pomiaru drgań oraz miejsce ich mocowania na badanym obiekcie na rys. 2 .

Do rejestracji sygnałów drgań zastosowano Multianalizator PULSE firmy Brüel\&Kjær. Aparaturę pomiarową na stanowisku diagnostycznym przedstawiono na rys. 3.

Przedstawione na rys. 3 urządzenie umożliwia rejestrację przebiegów szybkozmiennych równolegle na 17 kanałach z dynamiką do $160 \mathrm{~dB}$.

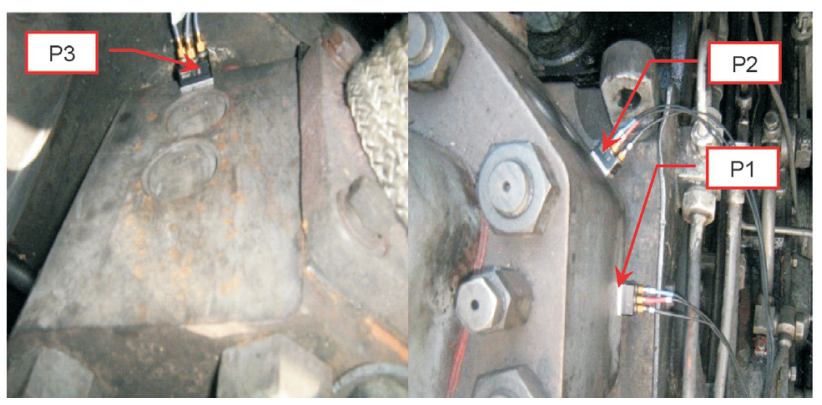

Fig. 2. Distribution of acceleration transducers on the cylinder head, engine a $8 \mathrm{C} 22$

Rys. 2. Rozmieszczenie przetworników drgań na głowicy cylindrów silnika a $8 C 22$
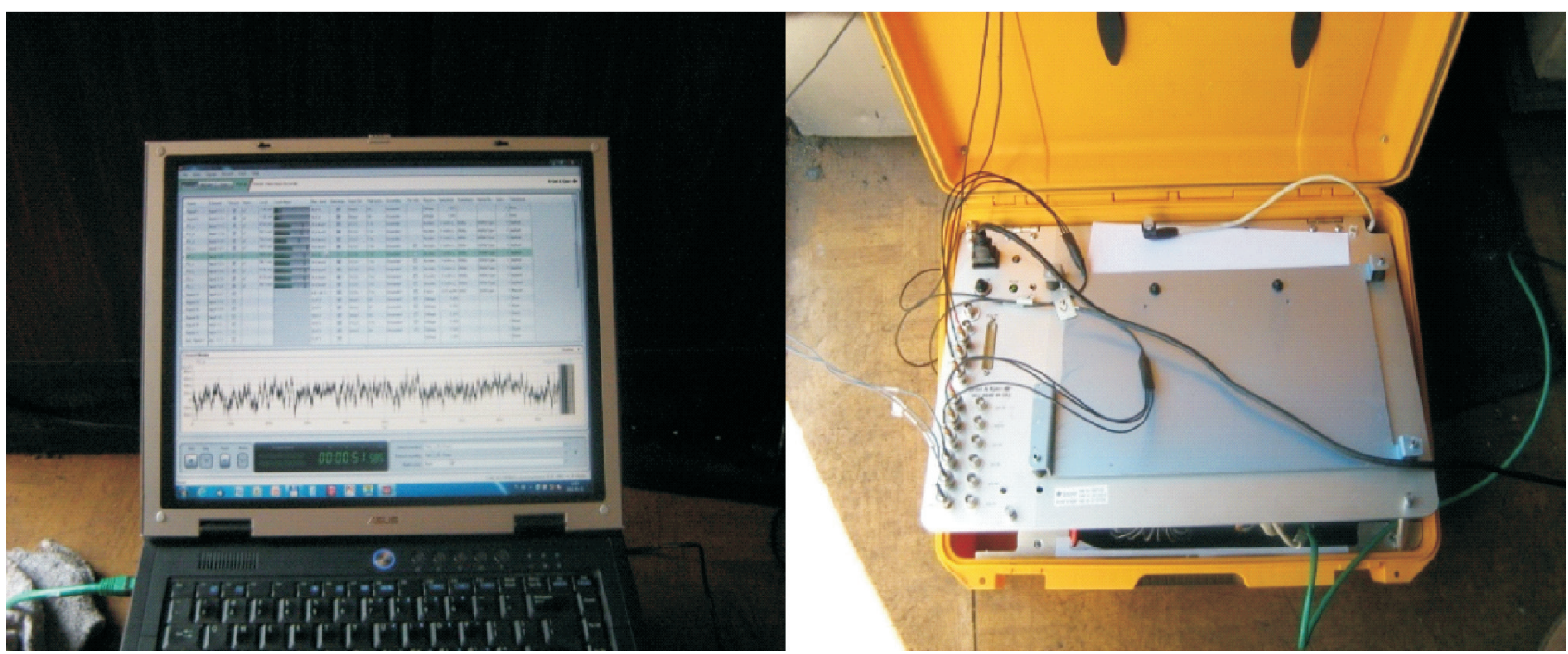

Fig. 3. View of the measurement equipment on the diagnostic post in Transporting Means Factory in Poznan Rys. 3. Aparatura pomiarowa na stanowisku diagnostycznym $w$ Zakładzie Taboru w Poznaniu 
The device shown in Fig. 3 enables the registration of the quick-changeable runs parallel on 17 ducts with the dynamics up to $160 \mathrm{~dB}$.

\section{Analysis of test results}

To make selection of the best point of signal acquisition for assessing the valve clearance, the pulse tests of the engine head were made and they consisted in impacting of the valves on the valve seats. The impacts were made by removing the standard plate placed between the valve stem and the valve rocker. To eliminate the casual errors and to obtain the averaging result, the operation described above was repeated several times on each of the valves. The aim was to determine such a vibration signals measurement place

\section{Analiza wyników badań}

W celu wyboru najlepszego punktu akwizycji sygnałów z punktu widzenia oceny luzu zaworów wykonano testy impulsowe głowicy polegające na uderzaniu zaworów o gniazda zaworowe. Uderzenia były realizowane przez usuwanie, umieszczonej pomiędzy trzonkiem zaworu a dźwigienką, płytki wzorcowej. Operację taką powtarzano kilkakrotnie dla każdego zaworu, aby wyeliminować przypadkowe błędy oraz umożliwić wykonanie procesu uśredniania. Celem badań było ustalenie takiego punktu pomiaru sygnałów drganiowych, który umożliwiałby ocenę procesu zderzenia każdego zaworu.

Analizy zarejestrowanych sygnałów wykonano w środowisku PULSE REFLEX [8]. Wykorzystane oprogramowanie

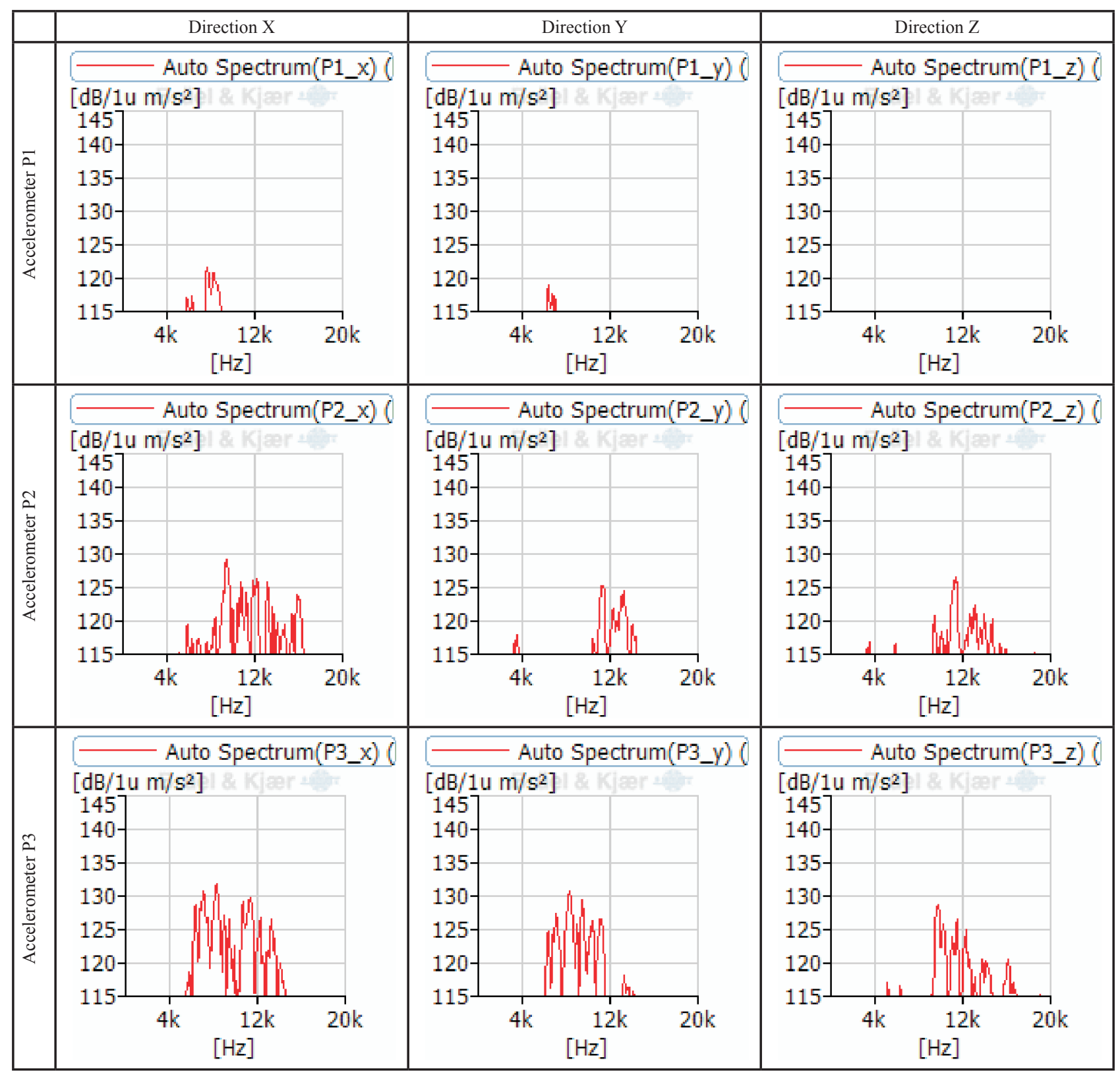

Fig. 4. The averaging amplitude spectrums of the vibration accelerations - left inlet valve impact Rys. 4. Uśrednione widma amplitudowe przyspieszeń drgań; uderzenie lewym zaworem dolotowym 


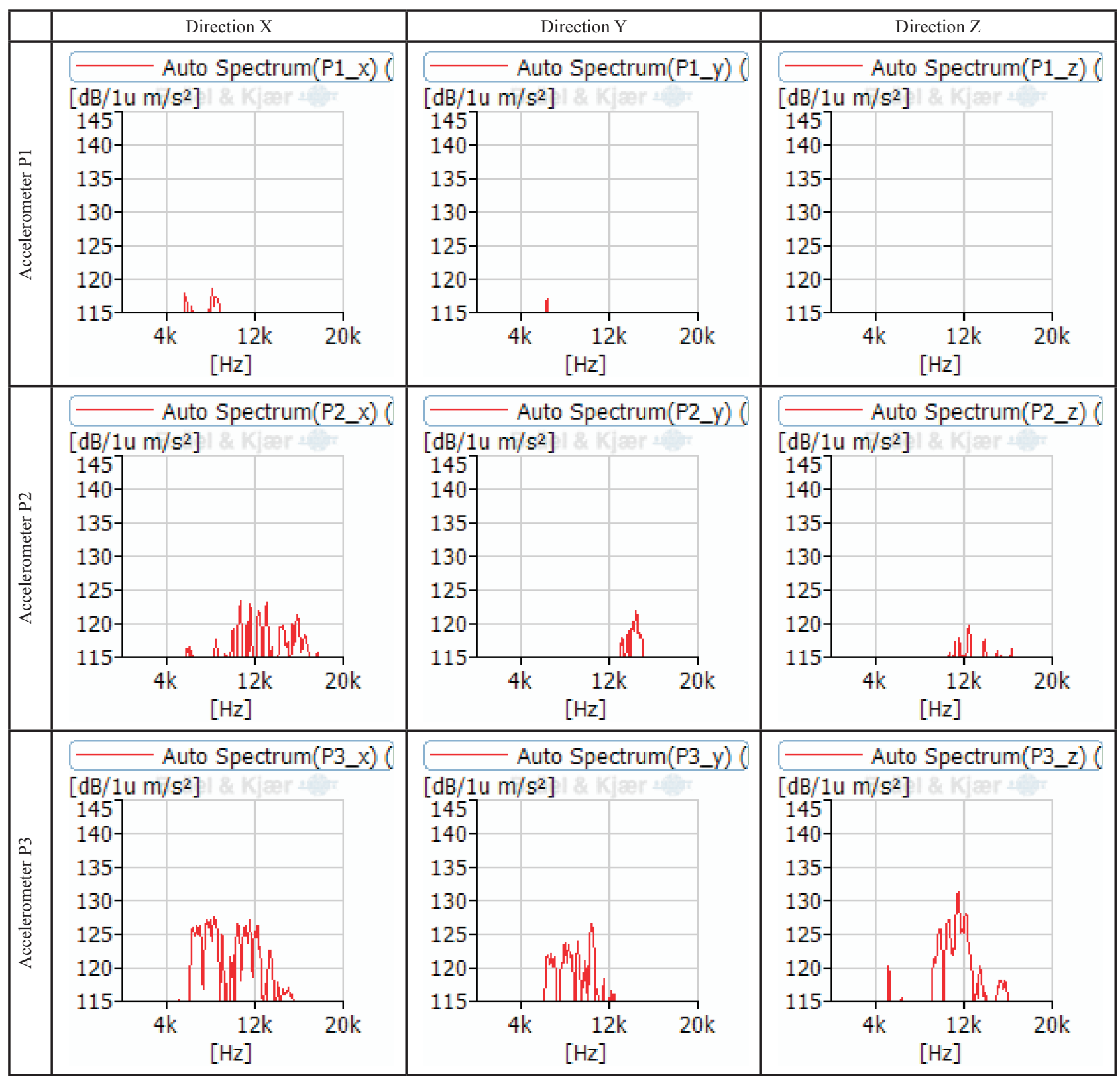

Fig. 5. The averaging amplitude spectrums of the vibration accelerations - right inlet valve impact

Rys. 5. Uśrednione widma amplitudowe przyspieszeń drgań; uderzenie prawym zaworem dolotowym

which would allow to make assessment of the impacting process on each valve. The analysis of the signals recorded were made in PULSE REFLEX [8] environment. The used software enabled to carry out an analysis of nine signals at the same time. Such an analysis variant gave opportunity to determine the influence of the impacts in each individual valve on the signals synchronously recorded in three different measurement points.

Selected tests results for determining the acquisition point of the vibration acceleration signals are shown in Figures $4-7$.

Figure 4 shows the averaging amplitude spectrums of the vibration acceleration signals synchronously recorded on three mutually perpendicular directions and in three different measurement points. The demonstrated spectrums are umożliwiało równoległą analizę dziewięciu sygnałów. Taki wariant analizy pozwalał na określenie wpływu uderzeń poszczególnych zaworów na sygnały rejestrowane synchronicznie w trzech różnych punktach pomiarowych.

Wybrane wyniki badań dotyczących wyznaczenia punktu akwizycji sygnałów przyspieszeń drgań przedstawiono na rys. $4-7$.

$\mathrm{Na}$ rysunku 4 przedstawiono uśrednione widma amplitudowe sygnałów przyspieszeń drgań zarejestrowanych synchronicznie w trzech wzajemnie prostopadłych kierunkach i trzech różnych punktach pomiarowych. Pokazane widma są wynikiem analizy sygnałów drganiowych będących następstwem zderzenia lewego zaworu dolotowego $\mathrm{z}$ gniazdem zaworu.

Uśrednione widma amplitudowe sygnałów przyspieszeń 


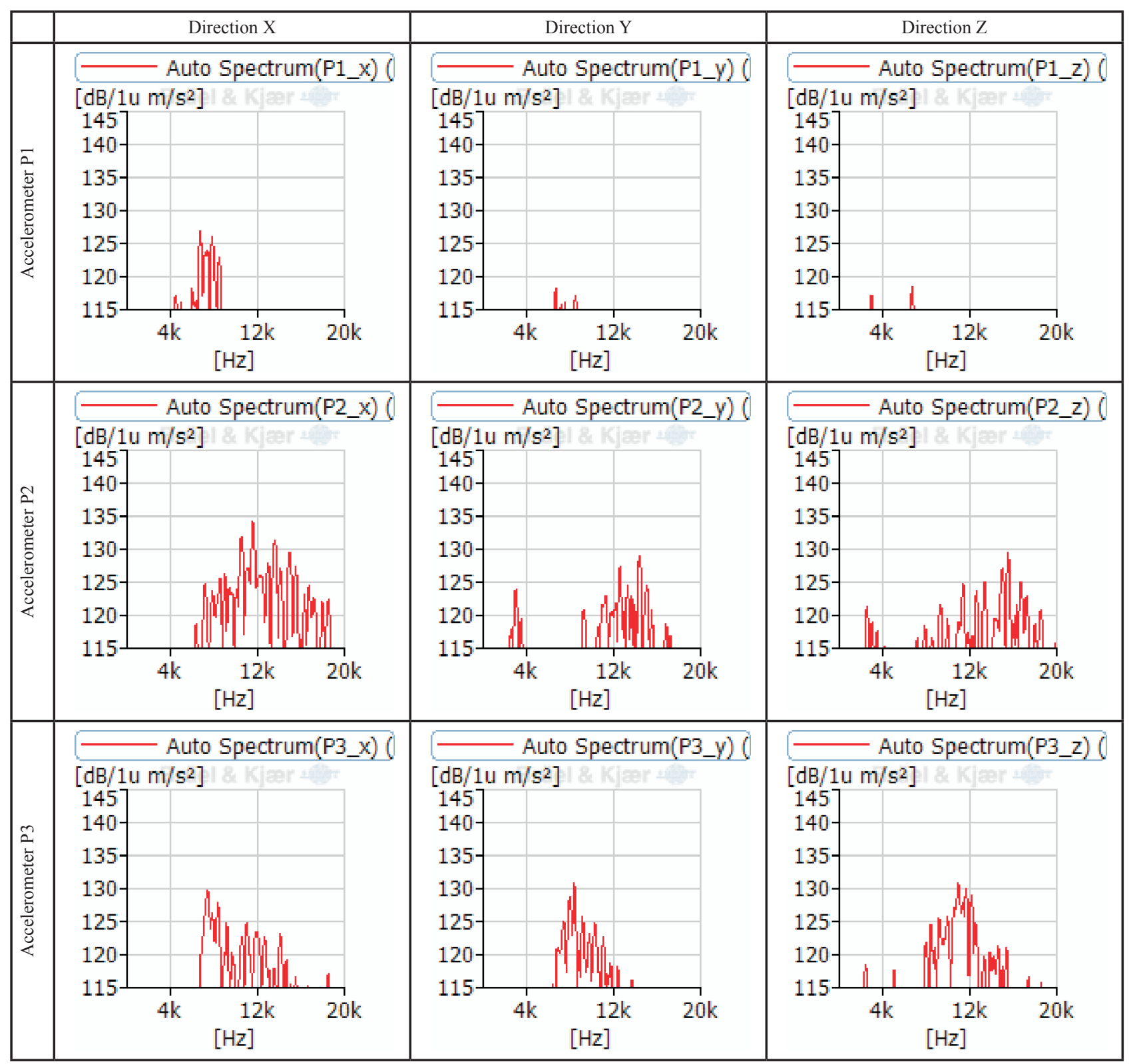

Fig. 6. The averaging amplitude spectrums of the vibration accelerations - right outlet valve impact

Rys. 6. Uśrednione widma amplitudowe przyspieszeń drgań; uderzenie prawym zaworem wylotowym

the results of the analysis of vibration signals being outcome of the left inlet valve impact on the valve seat.

Figure 5 contains the averaging amplitude spectrums of the vibration acceleration signals recorded in three mutually perpendicular directions and three different measurement points. The demonstrated spectrums are the analysis results of the vibration signals being the outcome of the right inlet valve impact on the valve seat.

As the result of an impact of the right outlet valve on the valve seat, a vibration signal was generated and its averaging frequency characteristics (averaging amplitude spectrums) are shown in Fig. 6. The signals of vibration accelerations were recorded taking into consideration three mutually perpendicular directions and in three different measurement points. drgań zarejestrowanych w trzech wzajemnie prostopadłych kierunkach i trzech różnych punkach pomiarowych przedstawiono na rys. 5. Widma są tu wynikiem analizy sygnałów drganiowych będących następstwem zderzenia prawego zaworu dolotowego z gniazdem.

$\mathrm{W}$ wyniku uderzenia prawego zaworu wylotowego z gniazdem został wygenerowany sygnał drganiowy, którego uśrednione charakterystyki częstotliwościowe (uśrednione widma amplitudowe) przedstawiono na rys. 6. Sygnały przyspieszeń drgań zarejestrowano w trzech wzajemnie prostopadłych kierunkach i trzech różnych punkach pomiarowych.

Uśrednione widma amplitudowe sygnałów przyspieszeń drgań zarejestrowanych w trzech wzajemnie prostopadłych kierunkach i trzech różnych punkach pomiarowych przedsta- 


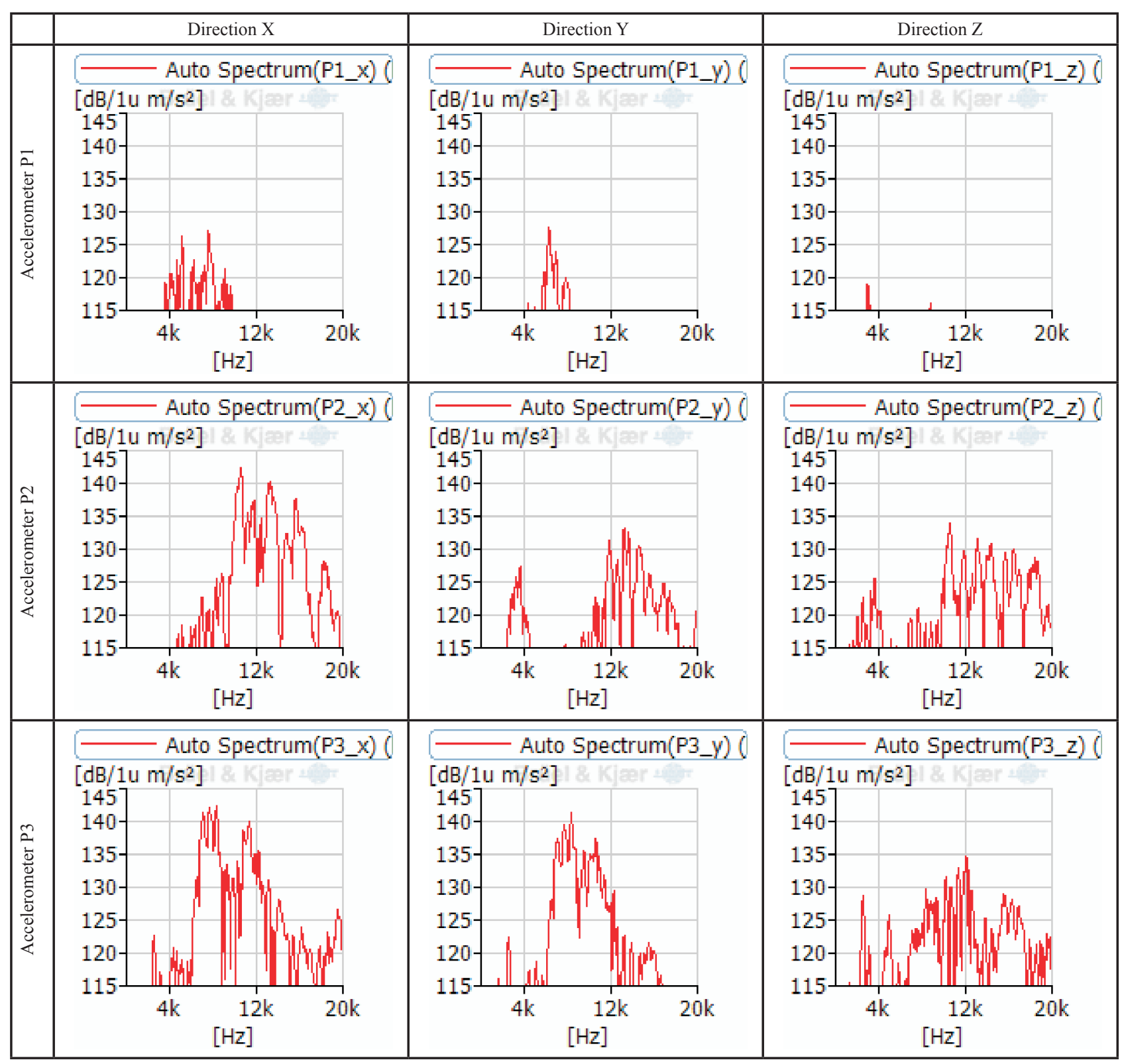

Fig. 7. The averaging amplitude spectrums of the vibration accelerations - left outlet valve impact

Rys. 7. Uśrednione widma amplitudowe przyspieszeń drgań; uderzenie lewym zaworem wylotowym

Figure 7 shows the averaging amplitude spectrums of the signals of vibration accelerations recorded on three mutually perpendicular directions and in three measurement points. Presented characteristics are the results of the analysis of vibration signals being the outcome of the left outlet valve and the valve seat smash.

From the characteristics shown in figures $4-7$, it appears that to assess the action correctness of valves adjustment system in an engine tested, the best thing is to apply the point P3 because it is characterized by the best dynamics and the smallest sensitivity for the changing of an impact place (the changing of the impact valve). To make an assessment of the valve operation, point $\mathrm{P} 1$ is much less useful. wiono na rys. 7 . Widoczne tu charakterystyki są wynikiem analizy sygnałów drganiowych będących następstwem zderzenia lewego zaworu wylotowego z gniazdem.

$\mathrm{Z}$ przedstawionych na rysunkach $4-7$ charakterystyk wynika, że do oceny poprawności działania układu regulacji zaworów badanego silnika najlepiej jest zastosować punkt P3, ponieważ charakteryzuje się on najlepszą dynamiką oraz najmniejszą wrażliwością na zmianę miejsca uderzenia (zmiana uderzającego zaworu). Najmniej przydatnym punktem pomiarowym do oceny pracy zaworów jest punkt P1.

\section{Podsumowanie}

W artykule przedstawiono metodę wspomagającą wybór punktów akwizycji sygnałów drgań, bazującą na analizie 


\section{Conclusion}

This paper shows a method which supports the choosing of the vibration signals acquisition points, it is based on an analysis of the test signals. This paper demonstrated that in the course of working out the test method is not enough to consider only the specialist literature and/or the some researcher's experience.

In described case all three measurement points met the requirements described in specialist literature, i.e. they were placed closest to the vibration source and they were easy accessible. However, to make an assessment of the valve clearance, by the frequency characteristics analysis on the basis of pulse test signals, point P3 was chosen.

Through the analysis of the presented test results it was found that the point of acquisition of the vibration signals, described as P1 should not be used for making an assessment of the valve clearance, because it is characterized by the low dynamics in the changes in the characteristics of spectrum test signals involving the action of valves.

It is possible to use measurement point P1 for making a diagnosis of the other elements of the cylinder head in combustion engine and the processes proceeding there and that is because the disorders caused by the valves and the valve seats smashes will be smaller than in the other taken into consideration points of a vibration acquisition. However, it is necessary first to make tests for proving the usefulness of this measurement point for a diagnostic testing. impulsowych sygnałów testowych. Wykazano, że podczas projektowania metodyki badań nie można kierować się tylko przesłankami literaturowymi i/lub doświadczeniem badacza.

W opisywanym przykładzie wszystkie trzy punkty pomiarowe spełniały warunki opisywane w literaturze, tzn. były położone blisko źródła drgań oraz były łatwo dostępne, jednak do oceny luzu zaworowego na podstawie analiz charakterystyk częstotliwościowych impulsowych sygnałów testowych wybrano punkt P3.

Na podstawie analizy przedstawionych wyników badań stwierdzono, że punkt akwizycji sygnałów drganiowych oznaczony P1 nie powinien być stosowany do oceny luzu zaworów, ponieważ charakteryzuje się niską dynamiką zmian charakterystyk widmowych sygnałów testowych związanych z pracą zaworów.

Istnieje możliwość zastosowania punktu pomiarowego P1 do diagnozowania innych elementów głowicy cylindrów silnika spalinowego lub procesów w niej zachodzących, ponieważ zakłócenia od zderzeń zaworów z gniazdami będą mniejsze niż w innych rozpatrywanych punktach akwizycji sygnałów drgań. Należy jednak przedtem wykonać testy potwierdzające przydatność tego punktu pomiarowego do diagnostyki.

Paper reviewed/Artykut recenzowany

\section{Bibliography/Literatura}

[1] Niziński S., Michalski R.: Diagnostyka obiektów technicznych, Biblioteka Problemów Eksploatacji Polskie Towarzystwo Diagnostyki Technicznej, Katedra Eksploatacji Pojazdów i Maszyn Wydziału Nauk Technicznych Uniwersytetu Warmińsko-Mazurskiego w Olsztynie, Instytut Technologii Eksploatacji w Radomiu, 2002.

[2] Czechyra B., Szymański G.M., Tomaszewski F.: Assessment of camvalves clearance in internal combustion engine based on parameters of vibration - methodological assumption, Combustion Engines No. 1/2004(118).

[3] Szymański G.M.: Analiza możliwości zastosowania wybranych charakterystyk sygnału drganiowego do diagnostyki silnika spalinowego. Rozprawa doktorska, Politechnika Poznańska, Poznań 2005.
[4] Osiecki J., Ziemba S.: Podstawy pomiarów drgań mechanicznych. PWN, Warszawa 1968.

[5] Serridge M., Licht T.R.: Piezoelectric accelerometers and vibration preamplifiers. Brüel \& Kjær 1987.

[6] Żółtowski B., Ćwik Z.: Leksykon diagnostyki technicznej. ATR, Bydgoszcz 1996.

[7] 4504A - Triaxial piezoelectric IEPE accelerometer, excl. cable (2012) [Online] available: http://www.bksv.com/products/ transducersconditioning/vibration-transducers/accelerometers/ accelerometers/4504a.aspx

[8] PULSE ReflexTM The product of intuition cable (2012) [Online] available: http://www.bksv.com/doc/bg1736.pdf
Prof. Franciszek Tomaszewski, DSc., DEng. - Professor in the Faculty of Working Machines and Transportation at Poznan University of Technology.

Dr hab. inż. Franciszek Tomaszewski - profesor na Wydziale Maszyn Roboczych i Transportu Politechniki Poznańskiej.

e-mail: franciszek.tomaszewski@put.poznan.pl

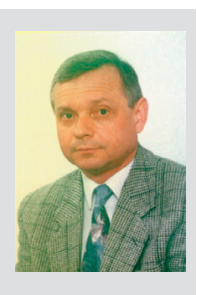

Grzegorz M. Szymański, DEng. - doctor in the Faculty of Working Machines and Transportation at Poznan University of Technology.

Dr inż. Grzegorz M. Szymański - adiunkt na Wydziale Maszyn Roboczych i Transportu Politechniki Poznańskiej.

e-mail: grzegorz.m.szymanski@put.poznan.pl 